\begin{tabular}{c} 
Volume and Issues Obtainable at Center for Sustainability Research and Consultancy \\
Journal of Accounting and Finance in Emerging Economies \\
ISSN: 2519-0318 ISSN (E) 2518-8488 \\
Volume 6: Issue 4 December 2020 \\
CSRC \\
Journal homepage: www.publishing.globalcsrc.org/jafee \\
\hline
\end{tabular}

\title{
Trade Liberalization, Economic Growth and Environmental Quality Nexus: An Empirical Evidence from Pakistan
}

\begin{tabular}{|c|c|}
\hline \multicolumn{2}{|c|}{$\begin{array}{c}{ }^{\mathbf{1}} \text { Noreen Safdar, }{ }^{\mathbf{2}} \text { Hina Ghaffar, }{ }^{\mathbf{3}} \text { Fatima Farooq, }{ }^{\mathbf{4}} \text { Malka Liaquat } \\
{ }^{1} \text { Assistant Professor, Department of Economics, The Women University Multan, Pakistan, } \\
\text { noreen.safdar@wum.edu.pk } \\
{ }^{2} \text { M.Phil Scholar, Department of Economics, The Women University Multan, Pakistan, } \\
{ }^{3} \text { Assistant Professor, School of Economics, Bahauddin Zakariya University Multan, Pakistan, } \\
\text { fatimafarooq@ @zu.edu.pk } \\
{ }^{4} \text { Assistant Professor, Institute of Management Science, The Women University Multan, Pakistan }\end{array}$} \\
\hline ARTICLE DETAILS & ABSTRACT \\
\hline $\begin{array}{l}\text { History } \\
\text { Revised format: November } \\
2020 \\
\text { Available Online: December } \\
2020\end{array}$ & $\begin{array}{l}\text { The linkage between trade liberalization, environmental quality and } \\
\text { economic growth is becoming an increasingly popular issue in } \\
\text { environmental economics in recent decades. In view of Pakistan's } \\
\text { position as one of the main contributors to carbon dioxide emissions } \\
\text { in Asia, it is vital to identify the main determinants of carbon }\end{array}$ \\
\hline $\begin{array}{l}\text { Keywords } \\
\text { Carbon dioxide emissions, } \\
\text { Trade Liberalization, growth, } \\
\text { Environmental Kuznets curve }\end{array}$ & $\begin{array}{l}\text { dioxide emissions. The present study empirically investigates the } \\
\text { long run association among trade liberalization, environmental } \\
\text { quality and economic growth along with other variables energy use } \\
\text { and capital labor ratio in Pakistan for the period 1980-2018. The }\end{array}$ \\
\hline $\begin{array}{l}\text { JEL Classification: } \\
M 02, M 21\end{array}$ & $\begin{array}{l}\text {-results also indicate that there is inverted } U \text { shape relationship } \\
\text { between economic growth and carbon dioxide emissions, hence the } \\
\text { environmental Kuznets curve hypothesis is valid in Pakistan during } \\
\text { 1980-2018. Trade openness has a negative significant impact on } \\
\text { carbon dioxide emissions. Capital labor ratio effects and energy use } \\
\text { have a direct relationship with carbon dioxide emissions. The results } \\
\text { show that environmental quality is first declined by economic } \\
\text { growth but with further increase in growth, environmental quality is } \\
\text { improved which supports the existence of Environmental Kuznet } \\
\text { curve hypothesis in Pakistan during that time span. Furthermore, } \\
\text { results also show that trade openness has positive significant impact } \\
\text { on environmental quality. }\end{array}$ \\
\hline
\end{tabular}

\section{OPEN ACCESS}

(C) 2020 The authors, under a Creative Commons AttributionNonCommercial 4.0

Corresponding author's email address: noreen.safdar@wum.edu.pk

Recommended citation: Safdar, N., Ghaffar, H., Farooq, F. \& Liaquat, M. (2020). Trade Liberalization, Economic Growth and Environmental Quality Nexus: An Empirical Evidence from Pakistan. Journal of Accounting and Finance in Emerging Economies, 6(4), 1077-1087

\section{Introduction}

Trade liberalization and clean environment are the most dynamic factors that donate very essential role for attaining economic development. Economic development is directly and indirectly affected by these factors. Some critics claim that subsequently increased trade liberalization encouraged higher growth and this must be cause to more industrial pollution and environmental degradation in developing 
countries. Furthermore, trade liberalization can deliver developing states with the encouragement to accept, the contact to new machineries which may give a cleaner or greener means of producing the good concerned. Trade is deliberated to be a catalytic agent for growth of economy. Trade has turn out to be an increasingly important economic movement, apparent from statistic that per year volume of trade expending sixteen times over period of last half century and grade of world's exports to gross domestic product achieving twenty percent. It is seen that trade improves standard of living of countries through descending their living costs thus eventually leads to growth. These are known economic returns or monetary profits related with the trade openness. While we consider the economic payoffs, the social returns are often neglected and here social payoffs mean environmental costs.

Trade openness may have positive or negative impact on environmental quality depending upon economic growth generally economic growth has negative environmental impact at initial stage of development due to increasing use of energy. Environmental quality is being worsen by increasing economic activities and energy use initially but at later stage of growth and development, it is being improved due to increasing demand of cleaner environment to accomplish higher living standard. Demand for clean energy and technology also upsurges at later stage of growth and development. It can be summarized as growth and environment degrades environment initially but helps to improve environmental quality later. This quadratic effect is also identified as environmental Kuznet curve hypothesis. This study also tests and supports the presence of EKC hypothesis in Pakistan for years 1990-2018 and highlights the positive environmental impact of trade.

This study inspects the impact of growth, trade liberalization and energy use on environmental quality in Pakistan for years 1990-2018.

\section{Literature Review}

Hakimi and Hamdi (2015) investigated financial effect of liberalization of trade on quality of environment in case of Morocco and Tunisia economies. This study covered the period from 1971-2013 with time series data. The conclusion revealed that liberalization of trade had an adverse influence on environmental quality. Therefore, study recommended to policymakers of these countries to focus on the dramatic significances of trade openness on wellbeing of their peoples and encourage liberalization of green trade.

Hellen (2015) inspected the causality between trade liberalization, environmental quality and growth of economy in Kenya. The time series data was taken from 1970- 2012 for a period of 42 years. The ecological footprint was used as a dependent variable while trade openness, real Gross domestic product, energy structure, energy use, and urbanization were used as an independent variable in this study. The study found that there was a negative association among environment and growth of economy. In a short time of period, there was a negative relation between trade openness and environmental quality, and trade had an optimistic consequence on the environment in long period of time.

Honma (2015) analyzed the influence of trade openness on environmental quality. The following study covered time span from 1970 to 2008 for 98 countries. The finding exposed that freer trade was positively related to environmental quality. Though, the influence of freer trade on quality of environment differed over countries. The conclusion showed greater income per capita was leading to additional advantage of trade on quality of environment.

Jabeen (2015) analyzed the casual linkage between trade openness, income growth, emissions and energy use for the case study of Pakistan by taking annual data over the period of $1980-2013$. The Cointegrated Vector Autoregressive technique and Johansen's Cointegration method were employed. The conclusion exposed that trade had a positive impact on environmental quality for Pakistan economy. On other side, energy use, income growth and energy had the negative influence on environmental quality thus provide indication for the Environmental Kuznets Curve in Pakistan. 
Jadon et al. (2015) estimated the linkage between liberalization of trade, human capital and growth for selected Asian economies. The panel data had been used from the period of 1981 to 2012. The fixed effect model was used to analyze influence of trade liberalization on growth of economy and human capital. The dependent variable was economic growth while independent variables total labor force, capital stock, trade openness was used in this study. The study concluded that there was positive linkage between these variables for selected period and for selected Asian economies. The influence of trade on human capital had positive for all Asian countries but because of skilled human capital it significant only for the developed nations. The developing countries had not been achieved this level due to less skilled human capital. The study recommended that developing countries should be focused on investment in human capital to gain more useful effects of trade openness.

Bernard and Mandal (2016) analyzed influence of liberalization of trade on efficiency of environment for 60 emerging countries. This study analyzed trade openness and environment nexus for the period 2002 to 2012. Random and fixed effects model were used for estimation. The conclusion showed that trade openness had no important influence on environmental performance index and had a noteworthy positive effect on carbon dioxide radiations.

Mujahid et al. (2016) analyzed effect of trade openness on growth of economy in case of Pakistan economy. This study was based on time span 1971 to 2013 and time series data. The conclusion found the long run linkage between these particular variables, furthermore, finding of Error Correction technique exposed adjustment of short-run equilibrium. The Independent variables such as imports and exports were positively related to the gross domestic product.

Abdillahi et al. (2017) studied influence of trade liberalization on growth of economy in Kenya. This study used yearly data taken from 1970-2014. The conclusion showed that investment and labor force had a noteworthy effect on growth of economy. It furthermore exposed that human capital had no important impact on growth of economy and there was a encouraging and notable linkage among liberalization and economic growth.

Fakher et al. (2017) studied nexus among environmental quality and growth of economy for selected developing states. The panel data was drawn from period of 1980-2012. The results indicated that economic growth was positively and considerably affected by trade liberalization. Furthermore, there was a optimistic and important influence of environmental quality on growth of economy and foreign direct investment had a progressive and noteworthy link with growth of economy.

Keho (2017) observed effect of trade on growth of economy for Cote d'Ivoire economy. This study covered the time span from 1965 to 2014. This study concluded that both in short and long run, trade had significant effects on economic growth. Moreover, there was a positive and strong linkage among freer trade and capital formation for accelerating economic growth.

Ofori and Asumadu (2017) studied the influence of FDI and trade on growth of economy of Ghana, based on annually time series data during time span 1986-2013. The result showed that gross domestic product and trade had significant optimistic effects in Ghana, while on the other hand, foreign direct investment inflows had a negative relation with gross domestic product growth.

Zahonogo (2017) inspected the effect of trade openness on growth of economy in the emerging economies, through more concentration on sub-Saharan Africa over the duration of 1980 to 2012. This study used the gross domestic product as a dependent and trade openness, inflation and external debt considered as independent variables. To estimate the long run equilibrium associations, Pooled Mean Group estimation method was employed. The conclusion found the association among liberalization and growth was significant and non-linear in long run for Sub Saharan Africa. 
Balin et al. (2018) examined the association among trade liberalization and environmental degradation of Turkey by utilizing the time series data for 1974-2013. Variables used in this study were energy use, carbon dioxide emission, investment inflows, gross domestic product and trade openness. The consequences found that there was a long run and significant association among per capita gross domestic product, carbon dioxide emissions, foreign direct investment and per capita energy consumption.

Armeanu et al. (2018) investigated association among environmental pollution and growth of economy by taking panel data which consisted of 28 European Union countries from the time period of 19402014. The conclusion confirmed the evidence of EKC hypothesis. Furthermore, there was a short run significant relation between radiations of greenhouse gases and gross domestic product per capita.

Nguyen et al. (2018) explored the effect of carbon dioxide emissions on growth of economy in situation of Vietnam. The study was based on annual time series data they ranged from the period of 1986 to 2015. The finding showed that air pollution and growth level had a significant relationship in Vietnam. Furthermore, this study also concluded that carbon dioxide emissions had an adverse influence on growth of economy in long run.

Alvi, et al. (2019) found the relationship of trade liberalization, FDI inflow and environmental quality with economic growth in Pakistan and China over the period 1989-2018. By using ARDL Bound testing technique, the results found that trade liberalization and FDI have positive influence on economic growth in both countries while environmental degradation has negative influence on economic growth in both Pakistan and China.

Nathaniel (2019) modeled energy consumption, urbanization and trade flow with respect to environment. The study utilized data of Nigeria from the years 1980-2016. CO2 emissions was used as dependent variable in the study while energy consumption, trade openness, urbanization square, GDP and urbanization were independent variables. The study used STIRPAT model. The study found out that energy consumption and urbanization increased emissions of $\mathrm{CO} 2$ while trade caused the opposite.

Alola et al. (2019) found out the influence of major factors on ecological footprint in Europe. The study used ecological footprint as dependent variable and GDP, fertility rate, non-renewable energy use, renewable energy use and trade openness were used as independent variables. Data of 16 EU countries was collected from 1997-2014. The study used PMG-ARDL methodology. The results revealed that use of non-renewable energy harmed for environmental quality although use of renewable energy improved it.

Mahmood et al. (2019) studied the influences of trade openness on CO2 emissions. The study composed data of Carbon dioxide emissions and trade openness of Tunisia for years 1971 to 2014. The study applied integration analysis. The results confirmed EKC for Tunisia, moreover, the results also suggested that increased foreign trade harmfully affected the environment thus confirming $\mathrm{PHH}$ in Tunisia.

Arif and Ullah (2019) analyzed the relation between globalization and CO2emissions for Pakistan. Over the years from 1975 to 2014. The study used CO2 emissions as dependent variable while economic globalization index, social globalization index, political globalization index, GDP and GDP square were used as independent variables. The study applied johansen cointegration and ARDL techniques. The results showed that globalization increased $\mathrm{CO} 2$ emissions, thus confirming EKC in case of Pakistan.

Jelbi et al. (2019) examined fundamental links among trade openness, energy use, tourism, FDI and economic growth. The data was collected from 22 central and South American states for years of 1995 to 2010. FMOLS and DOLS techniques were applied. The results showed bidirectional causality among 
trade, tourism, FDI, renewable energy, and emissions. Moreover, the results showed that trade and economic growth increased $\mathrm{CO} 2$ emissions while renewable energy, FDI and tourism condensed emissions.

Safdar et al. (2019) investigated the impact of environmental degradation on growth in 50 developing countries over the period of 1990 to 2016. By using PMG method, the study came to conclusion that energy use had positive link with growth while environmental degradation had negative link with growth.

Farooq et al. (2020) explored the impact of globalization and FDI on CO2 emission in OIC countries. By using GMM method, the study concluded that globalization and FDI are causing environmental degradation in low income OIC countries while reducing environmental degradation in high income OIC countries. In low OIC countries results supported the pollution heaven hypothesis while in high income OIC countries, there was evidence of pollution halo hypothesis. Furthermore, results concluded that institutional changes and urbanization also causing environmental degradation.

Murshed (2020) analyzed the effects of IC Trade on undergoing renewable energy transition, energy efficiency and clean cooking fuel access on environment in case of south Asian countries. The study employed CUP-BC and CUP-FM techniques. Data was collected from 2000-2016. The results depicted that ICT trade reduced energy intensity and increased renewable energy consumption. ICT trade was also found to be reducing $\mathrm{CO} 2$ emissions.

\section{Data and Methodology}

This part gives the variables that are selected on theoretical and empirical basis to find the connection between growth, trade openness and environmental quality in Pakistan. $\mathrm{CO}_{2}$ is used as the dependent variable and as a proxy of environmental quality while GDP, GDP ${ }^{2}$, energy use, trade openness and capital labor ratio are other independent variables.

\subsection{Time Period}

Time series data of Pakistan for time span 1975-2018 is being utilized to identify the association among dependent and the explanatory variables.

\subsection{Data Sources}

The study is grounded on the secondary type of data and the data is composed from WDI (World Development Indicator 2018) and Economic Survey of Pakistan.

\subsection{Specification of Model}

The study identifies the effect of GDP, energy use, trade openness and capital labor ratio on environmental quality.

$\mathrm{LNCO} 2=\beta 0+\beta 1 \mathrm{LNGDP}+\beta 2 \mathrm{LNEU}+\beta 3 \mathrm{LNTO}+\beta 4 \mathrm{LNK} / \mathrm{L}$

To test the validity of the Environmental Kuznets Curve hypothesis, the squared GDP variable is also included in above mentioned equation Therefore, the model is made as follows:

$\mathrm{LNCO}_{2} t=\beta 0+\beta 1 \mathrm{LNGDP} t+\beta 2 \mathrm{LNGDP}^{2} t+\beta 3 \mathrm{LNEU} t+\beta 4 \mathrm{LNTO} t+\beta 5 \mathrm{LNK} / \mathrm{L}+\varepsilon_{\mathrm{t}}$

\section{Whereas}

$\mathrm{CO}_{2}$ is Carbon dioxide emissions, GDP is Gross Domestic product, GDP ${ }^{2}$ is Square of gross domestic product, EU is Energy use, TO is Trade Openness and $\mathrm{K} / \mathrm{L}$ is Capital labor ratio

Here $\beta$ 's are the elasticities. Keeping in view of above model we evaluated the model to satisfy the hypothesis of study that is; the GDP is positively linked to environmental degradation while GDP ${ }^{2}$ is negatively related to environmental degradation and trade openness is negatively linked to environmental degradation.

\section{Results \& Discussion}


This portion of study gives results of unit root, short-run and long-run estimates of ARDL and diagnostics analysis of study.

\subsection{Unit Root Test}

To check that data is stationary or not we use AFD and PP tests. The results attained by these tests are as follows.

Table 1 Results of unit Root Test

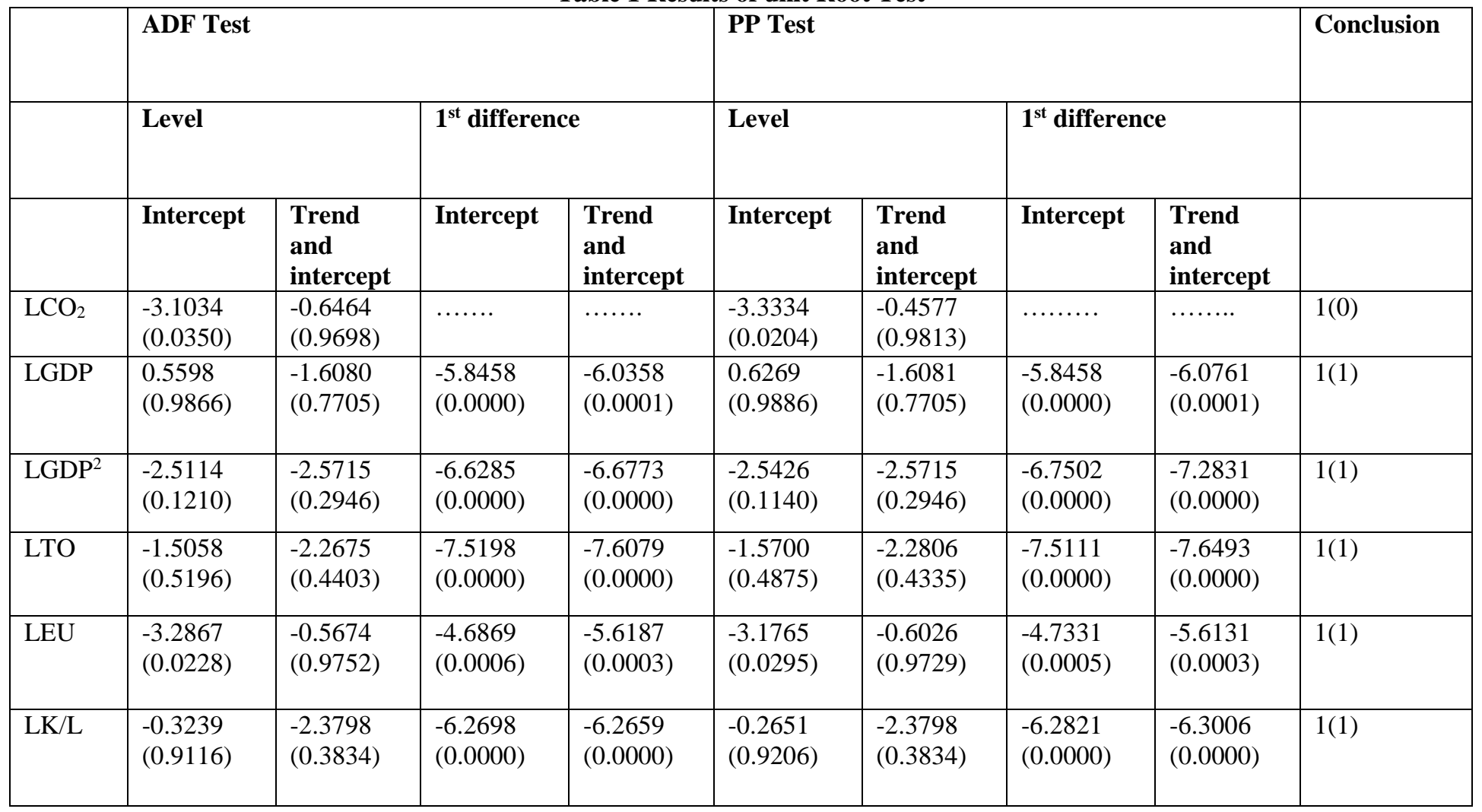

Table 1 displays the consequences of ADF and PP unit root test. The carbon dioxide emission is stationary at level While all other variables such as Gross domestic product and its square, energy use and capital labor ratio lie on $1^{\text {st }}$ difference. Hence, the results of unit root test are mix, so the (ARDL) method or technique is employed in our study. The bound test estimation is demonstrated to find the long run assessment of association amongst series of variables before employing the ARDL.

Table 2 Results of Bound Test

\begin{tabular}{|l|l|l|l|l|}
\hline & \multicolumn{2}{|l|}{ At 5\% Significance level } & \multicolumn{2}{l|}{ At 10\% Significance Level } \\
\hline F-Statistic & Lower bound & Upper Bound & Lower bound & Upper Bound \\
\hline 4.383354 & 2.62 & 3.79 & 2.26 & 3.35 \\
\hline
\end{tabular}

This table shows the bound method results. In this table, the F-statistics value is larger than upper bound at 5 and 10 percent level of significance so it is concluded that longrun relationship among chosen variables exists in our model.

\subsection{Estimates of ARDL Model}

Table 3 gives longrun, shortrun results of model. 
Table 3 (Results of ARDL Estimates

Dependent Variable: $\mathrm{CO}_{2}$

\begin{tabular}{|c|c|c|c|c|}
\hline \multicolumn{5}{|c|}{ ARDL Long Run Results } \\
\hline Variables & Coefficient & Std. Error & t-Statistic & Prob. \\
\hline LGDP & 0.001 & 0.047 & 0.089 & 0.029 \\
\hline LGDP $^{2}$ & -0.010 & 0.012 & -0.889 & 0.083 \\
\hline LTO & -0.085 & 0.104 & -0.817 & 0.042 \\
\hline $\mathrm{LK} / \mathrm{L}$ & 0.062 & 0.054 & 1.158 & 0.258 \\
\hline LEU & 1.512 & 0.091 & 16.694 & 0.000 \\
\hline $\mathrm{C}$ & -10.900052 & 0.390871 & -27.887 & 0.000 \\
\hline \multicolumn{5}{|c|}{ ARDL Short Run Results } \\
\hline $\mathrm{D}(\mathrm{LCO} 2(-1))$ & -0.251153 & 0.121896 & -2.060392 & 0.0504 \\
\hline D(LGDP) & 0.002711 & 0.030489 & 0.088913 & 0.9299 \\
\hline D(LGDP2) & -0.008412 & 0.007803 & -1.07797 & 0.2918 \\
\hline $\mathrm{D}(\operatorname{LGDP} 2(-1))$ & 0.013004 & 0.007596 & 1.711874 & 0.0998 \\
\hline $\mathrm{D}(\mathrm{LTO})$ & 0.043125 & 0.059277 & 0.727513 & 0.4739 \\
\hline $\mathrm{D}(\mathrm{LTO}(-1))$ & 0.167944 & 0.061521 & 2.72986 & 0.0117 \\
\hline $\mathrm{D}(\mathrm{LEU})$ & 1.024794 & 0.161755 & 6.33545 & 0.0000 \\
\hline D(LK_L) & 0.042416 & 0.033653 & 1.260387 & 0.2196 \\
\hline CointEq(-1) & -0.677542 & 0.114037 & -5.941407 & 0.0000 \\
\hline
\end{tabular}

Table 3 displays the results of Autoregressive Distributed Lag Model. The study comes to conclusion that one percent rise in GDP rises $\mathrm{CO}_{2}$ by 0.001 percent, the statistically important and positive association between GDP and $\mathrm{CO}_{2}$ emissions exists. As GDP increases, $\mathrm{CO}_{2}$ emission also increases. Further, the results show that square of GDP has statiscally negative relationship with $\mathrm{CO}_{2}$ emissions, somewhere 1 percent rise in $\mathrm{GDP}^{2}$ lessens $\mathrm{CO}_{2}$ emissions by approximately 0.011 percent. It indicates that the association between GDP, the Square of GDP and $\mathrm{CO}_{2}$ is inverted U-shaped which approves the presence of EKC hypothesis in Pakistan during time span 1990-2018. Our result is similar to McCraneys (2008); Ahmad (2015); Ali (2017) and Balin (2018).

Furthermore, the coefficient value of energy use is statistically substantial and positively associated with 
$\mathrm{CO}_{2}$ emissions. The 1 percent rise in EU increase the $\mathrm{CO}_{2}$ emissions by 1.51 percent. The positive relationship of $\mathrm{CO}_{2}$ with EU shows that Air pollution tends to rise as energy use increases. This explains that energy use has unfavorable effect on environmental quality. Our conclusion is in accordance with Ahmad (2015); Jabeen (2015) and Balin (2018).

The long run coefficient value of Trade openness is negative and statiscally significant which explains that 1 percent rise in trade declines $\mathrm{CO}_{2}$ emissions by 0.08 percent. The negative relationship among TO and $\mathrm{CO}_{2}$ shows that openness leads to improvement in environmental quality and there is a favorable consequence of trade openness on $\mathrm{CO}_{2}$. This finding is supported by study of Shabaz et al. (2012) who investigated that trade openness lessens carbon dioxide emissions due to technical change in Pakistan. This finding is also supported by the work of Ahmad (2015) and Jabeen (2015).

The coefficient value of $\mathrm{K} / \mathrm{L}$ is positive but statistically insignificant. one percent rise in $\mathrm{K} / \mathrm{L}$ rises the $\mathrm{CO}_{2}$ by 0.06 percent. This result is consistent with Cole (2006) who claimed that composition effect or $\mathrm{K} / \mathrm{L}$ ratio is positively associated with energy use and carbon dioxide emissions.

The short run analysis of this Model indicates most of variables are insignificant while signs are mixed.In this model, the sign of co integration coefficient is negative and the value of co integration is 0.677542 which is statistically significant. According to this value of coefficient, 67 percent of the discrepancy or inconsistency will be closed within the next year among the long-run and short-run.

\subsection{Diagnostic Analysis for Model}

This section indicates the fitness of model. In our study, different diagnostic tests are used to evaluate heteroskedasticity and auto-correlation analysis.

Table 4 Auto-correlation and Heteroskedasticity for Model

\begin{tabular}{|l|l|l|}
\hline \multicolumn{1}{|c|}{ Tests } & F-Statistics value & Probability \\
\hline $\begin{array}{l}\text { Breuch Godfry Serial } \\
\text { Correlation LM Test: }\end{array}$ & 1.871891 & 0.1775 \\
\hline $\begin{array}{l}\text { Heteroskedasticity Test: Breush } \\
\text { Pagan Godfry }\end{array}$ & 0.551727 & 0.8478 \\
\hline
\end{tabular}

The results of Diagnostic Analysis illustrate that there is no serial correlation and heteroscedasticity problem in our model.

\section{Conclusion \& Policy Suggestion}

The study identifies the impact of growth and trade openness on environmental quality in Pakistan for years 1980-2018. $\mathrm{CO}_{2}$ emission is used a proxy for inspecting environmental quality. The results show that environmental quality is first declined by economic growth but with further increase in growth, environmental quality is improved which supports the existence of Environmental Kuznet curve hypothesis in Pakistan during that time span.furthermore, results also show that the trade has positive substantial impact on environmental quality.

There are some policy implications that should be useful for policy makers to suggest policies in order to lessen the environmental degradation and improve environmental quality in Pakistan. These policy recommendations are as follows,

1. As the study comes to conclusion that environmental quality is being affected at first stage of growth and is being improved with further growth and development so government of Pakistan should take serious step to improve environmental quality from initial stage.

2. The study illustrations that trade openness has vital negative impact on environmental degradation in other words environmental quality is being improved with trade openness. Government of Pakistan should formulate such policies that gains from trade could be maximized and environmental cost could be minimized. 
3. The results indicate that environmental quality is badly affected by energy use, as energy use increases, environmental degradation also increases so government of Pakistan should ensure environmental friendly use of energy.

\section{References}

Abdillahi, U. A., \& Manini, M. M. (2017) Impact of Trade Openness on Economic Growth in Kenya.

Abdouli, M., \& Hammami, S. (2017). The impact of FDI inflows and environmental quality on economic growth: an empirical study for the mena countries. Journal of the Knowledge Economy, 8(1), 254-278.

Abdulai, A., \& Ramcke, L. (2009). The impact of trade and economic growth on the environment: revisiting the cross-country evidence (No. 1491). Kiel Working Paper.

Afonso, A. (2001). Non-Keynesian effects of fiscal policy in the EU-15.

Ahmed, K., \& Long, W. (2012). Environmental Kuznets curve and Pakistan: an empirical analysis. Procedia Economics and Finance, 1, 4-13.

Alam, S., Rehman, S., \& Butt, M. S. (2011). Trade liberalization, environmental degradation and sustainable development in Pakistan. European Journal of Social Sciences, 19(1), 84-96.

Ali, Z., Zaman, Z., \& Ali, M. (2015). The Effect of International Trade on Carbon Emissions: Evidence from Pakistan. Journal of Economics and Sustainable Development, 6(9), 289-299.

Alola, A. A., Bekun, F. V., \& Sarkodie, S. A. (2019). Dynamic impact of trade policy, economic growth, fertility rate, renewable and non-renewable energy consumption on ecological footprint in Europe. Science of the Total Environment, 685, 702-709.

Alvi, S., Chaudhry, I. S., Farooq, F., \& Safdar, N. (2019). Trade liberalization, foreign direct investment inflows, environmental quality and economic growth nexus: a comparative analysis of Pakistan and China. Review of Applied Management \& Social Science, 2(1), 17-26.

Antweiler, W., Copeland, B. R., \& Taylor, M. S. (2001). Is free trade good for the environment? American Economic Review, 91(4), 877-908.

Appiah-Konadu, P. A. U. L. (2013). The Effect of Trade Liberalization on the Environment: A Case Study of Ghana (Doctoral dissertation, University of Ghana).

Armeanu, D., Vintilă, G., Andrei, J. V., Gherghina, Ş. C., Drăgoi, M. C., \& Teodor, C. (2018). Exploring the link between environmental pollution and economic growth in EU-28 countries: Is there an environmental Kuznets curve? PloS one, 13(5), e0195708.

Azhar, U., Khalil, S., \& Ahmed, M. H. (2007). Environmental effects of trade liberalization: a case study of Pakistan. The Pakistan Development Review, 645-655.

Badinger, H. (2001). Growth effects of economic integration. The case of the EU Member States (19502000).

Baldwin, R. E. (2004). Openness and growth: What's the empirical relationship?. In Challenges to globalization: Analyzing the economics (pp. 499-526). University of Chicago Press.

Balin, B. E., Akan, H. D. M., \& Altayligil, Y. B. Trade Liberalization and Environmental Degradation: A Time series analysis for Turkey.

Bernard, J., \& Mandal, S. K. (2016). The impact of trade openness on environmental quality: an empirical analysis of emerging and developing economies. WIT Transactions on Ecology and the Environment, 203, 195-208.

Busse, M., \& Königer, J. (2012). Trade and economic growth: A re-examination of the empirical evidence. Available at SSRN 2009939.

Cole, M. A. (2006). Does trade liberalization increase national energy use? Economics Letters, 92(1), 108-112.

Copeland, B. R., \& Taylor, M. S. (2004). Trade, growth, and the environment. Journal of Economic literature, 42(1), 7-71.

Din, M. U., Ghani, E., \& Siddique, O. (2003). Openness and economic growth in Pakistan. The Pakistan Development Review, 795-807.

Fakher, H. A., \& Abedi, Z. (2017). Relationship between Environmental Quality and Economic Growth in Developing Countries (based on Environmental Performance Index). Environmental Energy 
and Economic Research, 1(3), 299-310.

Farooq, F., Chaudhry, I. S., Yusop, Z., \& Habibullah, M. S. (2020). How do globalization and foreign direct investment affect environmental quality in OIC member countries?. Pakistan Journal of Commerce and Social Sciences (PJCSS), 14(2), 551-568.

Feridun, M., Ayadi, F. S., \& Balouga, J. (2006). Impact of trade liberalization on the environment in developing countries: the case of Nigeria. Journal of developing societies, 22(1), 39-56.

Frankel, J., \& Rose, A. (2002). An estimate of the effect of common currencies on trade and income. The Quarterly Journal of Economics, 117(2), 437-466.

Gale, L. R., \& Mendez, J. A. (1998). The empirical relationship between trade, growth and the environment. International Review of Economics \& Finance, 7(1), 53-61.

Hakimi, A., \& Hamdi, H. (2016). Trade liberalization, FDI inflows, environmental quality and economic growth: a comparative analysis between Tunisia and Morocco. Renewable and Sustainable Energy Reviews, 58, 1445-1456.

Hellen, S. N. (2017). Enviornmental Quality, Trade openness and Economic Growth in Kenya.

Jebli, M. B., Youssef, S. B., \& Apergis, N. (2019). The dynamic linkage between renewable energy, tourism, $\mathrm{CO} 2$ emissions, economic growth, foreign direct investment, and trade. Latin American Economic Review, 28(1), 2.

Jobert, T., Karanfil, F., \& Tykhonenko, A. (2016). Trade and environment: further empirical evidence from heterogeneous panels using aggregate data (No. halshs-01295613).

Karsalari, A. R., Mehrara, M., Musai, M., \& Mohammadi, M. (2014). Relationship between economic growth, trade and environment: evidence from D8 countries. IJARAFMS, 4, 320-326.

Keho, Y. (2017). The impact of trade openness on economic growth: The case of Cote d'Ivoire. Cogent Economics \& Finance, 5(1), 1332820.

Khan, D., \& Ullah, A. (2019). Testing the relationship between globalization and carbon dioxide emissions in Pakistan: does environmental Kuznets curve exist?. Environmental Science and Pollution Research, 26(15), 15194-15208.

Kim, N. T., \& Le, M. B. (2018). Co2 Emissions and Economic Growth in Vietnam: An ARDL Bound Testing Approach. Asian Journal of Economic Modelling, 6(1), 47-55.

Kraay, A., \& Dollar, D. (2001). Trade, growth, and poverty. The World Bank.

Krueger, A. O. (1997). Free trade agreements versus customs unions. Journal of Development Economics, 54(1), 169-187.

Krueger, A. O. (1997). Trade policy and economic development: how we learn (No. w5896). National Bureau of Economic Research.

Ling, C. H., Ahmed, K., Muhamad, R. B., \& Shahbaz, M. (2015). Decomposing the trade-environment nexus for Malaysia: what do the technique, scale, composition, and comparative advantage effect indicate?. Environmental Science and Pollution Research, 22(24), 20131-20142.

Loi, N. (2012). The impact of trade liberalization on the environment in some East Asian countries: an empirical study.

Mahmood, H., Maalel, N., \& Zarrad, O. (2019). Trade openness and CO2 emissions: Evidence from Tunisia. Sustainability, 11(12), 3295.

Managi, S., Hibiki, A., \& Tsurumi, T. (2008). Does trade liberalization reduce pollution emissions. Discussion papers, 8013.

Mukhopadhyay, K., \& Chakraborty, D. (2005). Is liberalization of trade good for the environment? Evidence from India. Asia Pacific Development Journal, 12(1), 109.

Murshed, M. (2020). An empirical analysis of the non-linear impacts of ICT-trade openness on renewable energy transition, energy efficiency, clean cooking fuel access and environmental sustainability in South Asia. Environmental Science and Pollution Research, 27(29), 3625436281.

Naranpanawa, A. (2011). Does trade openness promote carbon emissions? Empirical evidence from Sri Lanka. The Empirical Economics Letters, 10(10), 973-986.

Nathaniel, S. P. (2019). Modelling urbanization, trade flow, economic growth and energy consumption with regards to the environment in Nigeria. GeoJournal, 1-15. 
Ofori, D., \& Asumadu, G. (2017). Foreign Direct Investment, Trade and Economic Growth in Ghana: An Empirical Analysis. International Research Journal of Finance and Economics, (159).

Omri, A., Daly, S., Rault, C., \& Chaibi, A. (2015). Financial development, environmental quality, trade and economic growth: What causes what in MENA countries. Energy Economics, 48, 242-252.

Parikh, A., \& Stirbu, C. (2004). Relationship between trade liberalization, economic growth and trade balance: an econometric investigation.

Qureshi, M. S. (2008). Trade liberalization, environment and poverty: a developing country perspective. In Globalization and the Poor in Asia (pp. 250-287). Palgrave Macmillan, London.

Rodriguez, F., \& Rodrik, D. (2000). Trade policy and economic growth: a skeptic's guide to the crossnational evidence. NBER macroeconomics annual, 15, 261-325.

Schiff, M., \& Winters, L. A. (2003). Regional integration and development. The World Bank.

Shafik, N. (1994). Economic development and environmental quality: an econometric analysis. Oxford economic papers, $46(4), 757-774$.

Shahbaz, M., Lean, H. H., \& Shabbir, M. S. (2012). Environmental Kuznets curve hypothesis in Pakistan: cointegration and Granger causality. Renewable and Sustainable Energy Reviews, 16(5), 2947-2953.

Umer, F. (2014). Impact of trade openness on economic growth of Pakistan: An ARDL approach. Journal of Business and Economic Policy, 1(1), 39-59.

Zahonogo, P. (2016). Trade and economic growth in developing countries: Evidence from sub-Saharan Africa. Journal of African Trade, 3(1-2), 41-56. 